\title{
FAKTOR-FAKTOR YANG BERHUBUNGAN DENGAN SIKLUS MENSTRUASI PADA REMAJA PUTRI KELAS XI DI SMA NEGERI 6 TANGERANG SELATAN
}

\author{
Ayatun Fil Ilmi, Elyn Widya Selasmi \\ Sekolah Tinggi Ilmu Kesehatan Kharisma Persada \\ Tangerang Selatan, 15417, Indonesia \\ E-mail: ayatun@masda.ac.id
}

\begin{abstract}
ABSTRAK
Menstruasi adalah pengeluaran darah dan sisa endometrium dari vagina. Hari pertama menstruasi dianggap sebagai permulaan siklus baru. Siklus menstruasi adalah jarak antara tanggal mulainya menstruasi yang lalu dan mulainya menstruasi yang akan datang. Siklus menstruasi yang tidak teratur mengakibatkan infertilitas, $28 \%$ peningkatan risiko jantung koroner, dan diabetes mellitus tipe 2. Tujuan penelitian ini adalah mengetahui faktor yang berhubungan dengan siklus menstruasi pada Remaja Putri Kelas XI di SMA N 6 Kota Tangerang Selatan. Desain studi pada penelitian ini adalah cross sectional dengan pengambilan sampel menggunakan metode simple random sampling. Sampel penelitian berjumlah 64 orang yang berasal dari remaja putri kelas XI SMA N 6 Kota Tangerang Selatan. Variabel yang diteliti status gizi, tingkat stres, aktifitas fisik, dan usia menarche. Data mengenai siklus menstruasi, tingkat stres, aktivitas fisik diperoleh dengan wawancara sementara Indeks Massa Tubuh dengan pengukuran berat badan dan tinggi badan. Pengolahan data dilakukan dengan analisis uji chi square. Hasil penelitian menunjukkan sebanyak 59,4\% responden mengalami siklus menstruasi tidak teratur. Terdapat hubungan yang signifikan antara usia menarche $(p$-value $=0,028)$ dengan siklus menstruasi. Dan terdapat kecenderungan kategori status gizi gemuk $(63,2 \%)$ untuk memiliki siklus menstruasi tidak teratur. Kesimpulan dari hasil analisis data tersebut dapat disimpulkan bahwa ada hubungan antara usia menarche dengan siklus menstruasi. Dan tidak terdapat hubungan antara status gizi ( $p$ value $=0,822$ ) dengan siklus menstruasi.
\end{abstract}

Kata Kunci : : Siklus menstruasi, aktivitas fisik, imt/u, usia menarche, tingkat stres

\begin{abstract}
Menstruation is the release of blood and the rest of the endometrium from the vagina. The first day of menstruation is considered to be the beginning of a new cycle. Menstrual cycle is the distance between the date of the start of a previous menstruation and the onset of menstruation. Irregular menstrual cycles can be received by infertility, 28\% Increased risk of coronary heart disease, and type 2 diabetes mellitus. The aim of this study is to study the factors related to the menstrual cycle in adolescent girls in South Tangerang City Senior High School 6. Study design: in this study was cross sectional with sampling using the simple random sampling method. The study sample returned 64 people from the XI class of SMA Negeri 6 South Tangerang City. The variables that are issued are nutritional status, stress level, physical activity, and age of menarche. Data about the menstrual cycle, stress level, physical activity obtained by temporary interviews of the Body Mass Index by measuring body weight and height. Data processing is done by chi square test analysis. Results: Research shows as many as 59.4\% of respondents who experience irregular menstrual cycles. There was a significant relationship between menarche age $(p=0.028)$ with the menstrual cycle. And balanced nutritional status (63.2\%) to have irregular menstrual cycles. Conclusion: From the results of the analysis of the data it can be concluded that there is a relationship between the age of menarche and the menstrual cycle. And there is no relationship between nutritional status $(p=0.822)$ with the menstrual cycle.
\end{abstract}

Keywords $\quad$ : Menstrual Cycle, physical activity, BMI / U, the age of menarche, stress level 


\section{PENDAHULUAN}

Siklus menstruasi merupakan jarak antara tanggal mulainya menstruasi yang lalu dan mulainya menstruasi yang baru. Siklus menstruasi pada perempuan normalnya terjadi setiap 21-35 hari sekali dengan lama menstruasi berkisar 5-7 hari. Siklus menstruasi yang bagus berlangsung selama 28 hari. Hanya 10-15\% perempuan yang memiliki siklus 28 hari. Jika siklusnya tidak lancar seperti lama menstruasi yang panjang atau terlalu cepat, hal ini mungkin disebabkan oleh gangguan pada rahim atau gangguan pada indung telurnya. Namun bila keduanya baik-baik saja, kemungkinan karena terjadi gangguan pada hormon bisa juga karena pengaruh gizi (Pribakti, 2012 dan Madaras, 2011).

Berdasarkan hasil riskesdas (2010) menunjukkan bahwa siklus menstruasi teratur pada perempuan usia 10-59 tahun di Indonesia mencapai 68,0\% sedangkan siklus menstruasi yang tidak teratur yakni $13,7 \%$. Sebanyak $14,9 \%$ remaja perempuan yang tinggal di daerah perkotaan di Indonesia mengalami siklus menstruasi tidak teratur. Hasil penelitian yang dilakukan oleh Pratiwi (2011) di SMA 1 Mojolaban, Solo menunjukkan bahwa sebesar $41,8 \%$ siswi mengalami siklus menstruasi tidak teratur sementara di SMA 1 Kendal, Jawa Tengah terdapat
43,9\% remaja kelas 1 dan 2 yang mengalami siklus tidak teratur. Berdasarkan hasil studi pendahuluan yang telah dilakukan pada 30 April 2019 terhadap 16 siswi. Terdapat 56,25\% siswi yang mengalami siklus menstruasi yang tidak normal yaitu dengan panjang siklus menstruasi $<21$ hari dan $31,25 \%$ siswi yang mengalami siklus menstruasi dengan panjang $>35$ hari.

Dampak menstruasi tidak teratur adalah infertile, endometriosis, dan gangguan psikologis. Infertile bisa terjadi jika siklus menstruasi tidak teratur sehingga mengakibatkan ovulasi terganggu dan dapat terjadi ketidakseimbangan hormonal yang memiliki pengaruh besar terhadap ovulasi.

Siklus menstruasi tidak teratur juga dapat dipengaruhi oleh status gizi, hal ini berhubungan dengan perubahan kadar hormon steroid yang merupakan faktor dalam proses pengaturan siklus menstruasi. Kurangnya gizi atau terbatasnya asupan gizi selain akan mempengaruhi pertumbuhan, fungsi organ tubuh, juga akan menyebabkan terganggunya fungsi reproduksi. Hal ini bisa berdampak pada gangguan menstruasi, namun akan membaik bila asupan nutrisinya juga baik. Stres 
merupakan salah satu faktor yang mempengaruhi siklus menstruasi.

Hasil beberapa penelitian menyatakan adanya perbedaan yang signifikan antara tingkat stres dengan siklus menstruasi tidak teratur. Aktivitas fisik juga merupakan faktor yang dapat mempengaruhi siklus menstruasi. Penelitian yang dilakukan oleh Hikmah (2016) menunjukkan bahwa aktivitas fisik yang berat dapat mempengaruhi siklus menstruasi $(75,8 \%)$ sedangkan pada aktivitas ringan atau sedang $(66,7 \%)$ tidak mempengaruhi siklus menstruasi.

\section{METODE}

Penelitian ini menggunakan desain cross sectional yang mana pengambilan data variabel dependen dan variabel independen dilakukan dalam waktu bersamaan. Sifat penelitian ini analitik yaitu akan melihat hubungan antara variabel dependen dan variabel independen. Variabel yang di teliti yaitu status gizi antropometri (IMT/U), stres, dan aktivitas fisik, dan usia menarche pada siswi kelas XI di SMA Negeri 6 Kota Tangerang Selatan dan untuk variabel independen pada penelitian ini yaitu siklus menstruasi. Sampel pada penelitian ini adalah siswi kelas XI di SMA Negeri 6 Kota Tangerang Selatan sebanyak 64 siswi.

Sampel diambil menggunakan teknik Simple Random Sampling. Instrumen digunakan kuesioner dan pengukuran berat badan dan tinggi badan. Analisis data dilakukan secara univariat dan bivariat menggunakan Uji pearson untuk mengetahui hubungan status gizi dengan siklus menstruasi, hubungan stres dengan siklus menstruasi, hubungan aktivitas fisik dengan siklus menstruasi, dan hubungan usia menarche dengan siklus menstruasi.

\section{HASIL}

\section{Analisis Univariat}

Proporsi siswi yang mengalami siklus menstruasi tidak teratur lebih banyak dibandingkan dengan responden yang memiliki siklus menstruasi yang teratur. Jumlah responden yang memiliki siklus menstruasi tidak teratur yaitu 38 responden $(59,4 \%) \quad$ sedangkan 26 responden lainnya $(40,6 \%)$ memiliki menstruasi teratur (Tabel 1).

Tabel 1. Gambaran Riwayat Siklus Menstruasi Remaja Putri Kelas XI di SMA N 6 Kota Tangerang Selatan

\begin{tabular}{lcc}
\hline Siklus Menstruasi & Jumlah $(\mathrm{n})$ & Persentase $(\%)$ \\
\hline Tidak teratur & 38 & 59,4 \\
Teratur & 26 & 40,6 \\
\hline
\end{tabular}




\section{Analisis Bivariat}

Berikut adalah hasil bivariat penelitian ini:

Tabel 2. Perbedaan Proporsi Karakteristik Responden terhadap Siklus Menstruasi

\begin{tabular}{|c|c|c|c|c|c|c|}
\hline \multirow[t]{2}{*}{ Variabel } & \multirow[t]{2}{*}{ Kategori } & \multicolumn{2}{|c|}{$\begin{array}{c}\text { Siklus } \\
\text { Menstruasi } \\
\text { Tidak Teratur } \\
\end{array}$} & \multicolumn{2}{|c|}{$\begin{array}{c}\text { Siklus } \\
\text { Menstruasi } \\
\text { Teratur } \\
\end{array}$} & \multirow[t]{2}{*}{ p-value } \\
\hline & & $\mathbf{n}$ & $\%$ & $\mathbf{n}$ & $\%$ & \\
\hline \multirow{4}{*}{ Status Gizi } & Obesitas & 13 & 59,1 & 9 & 40,9 & \multirow{4}{*}{0,822} \\
\hline & Gemuk & 12 & 63,2 & 7 & 36,8 & \\
\hline & Normal & 11 & 61,2 & 7 & 38,9 & \\
\hline & Kurus & 2 & 40 & 3 & 60 & \\
\hline \multirow{4}{*}{ Tingkat Stres } & Tinggi & 13 & 72,2 & 5 & 27,8 & \multirow{4}{*}{0,037} \\
\hline & Sedang & 14 & 77,8 & 4 & 22,2 & \\
\hline & Rendah & 10 & 40,0 & 15 & 60,0 & \\
\hline & Tidak Mengalami & 1 & 33,3 & 2 & 66,7 & \\
\hline \multirow{4}{*}{ Aktivitas Fisik } & Sangat Berat & 16 & 69,6 & 7 & 30,4 & \multirow{4}{*}{0,246} \\
\hline & Berat & 10 & 66,7 & 5 & 33,3 & \\
\hline & Sedang & 9 & 52,9 & 8 & 47,1 & \\
\hline & Ringan & 3 & 33,3 & 6 & 66,7 & \\
\hline \multirow{3}{*}{ Usia Menarche } & Cepat <11 Tahun & 17 & 70,8 & 7 & 29,2 & \multirow{3}{*}{0,028} \\
\hline & Normal 12-13 Tahun & 7 & 35,0 & 13 & 65,0 & \\
\hline & Lambat 14-16 Tahun & 14 & 70,0 & 6 & 30,0 & \\
\hline
\end{tabular}

\section{DISKUSI}

Status gizi pada penelitian ini dikelompokkan dalam empat kelompok, yakni kurus, normal, gemuk, dan obesitas. Berdasarkan tabel 2. diketahui bahwa sebagian besar siswi SMA Negeri 6 Kota Tangerang Selatan memiliki nilai status gizi obesitas sebanyak 22 responden $(34,4 \%)$ sedangkan siswi dengan status gizi kurus sebanyak 5 responden $(7,8 \%)$.

Tingkat stres pada penelitian ini dikelompokkan dalam 4 kelompok, yakni tidak mengalami (skor <20), rendah (skor 21-24), sedang (skor 25-29), dan tinggi (skor >30). Berdasarkan tabel 2 diketahui bahwa responden yang memiliki tingkat stres rendah sebanyak 25 responden $(39,1 \%)$ sedangkan siswi yang mengalami tingkat stres yang tinggi dan sedang sebanyak 18 responden $(28,1 \%)$.

Aktivitas fisik pada penelitian ini dikelompokkan dalam empat kelompok, yakni ringan, sedang, berat dan sangat berat. Berdasarkan tabel 2 diketahui bahwa responden yang memiliki tingkat aktivitas fisik yang sangat berat sebanyak 23 responden $(35,9 \%)$ sedangkan responden yang memiliki aktivitas fisik yang ringan sebanyak 9 responden $(14,1 \%)$. Usia menarche pada penelitian ini dikelompokkan dalam tiga 
kelompok, yakni lambat (14-16 tahun), normal (12-13 tahun), dan cepat $(<11$ tahun).

Berdasarkan tabel 2 diketahui bahwa responden yang mengalami usia menarche cepat dimana usia tersebut seseorang mendapatkan haid pertamanya sebanyak 24 responden $(37,5)$ dan responden yang mengalami usia menarche normal atau lambat sebanyak 20 responden $(31,3 \%)$.

Hasil analisis statistik pada Tabel 2 menunjukkan bahwa tidak ada hubungan antara status gizi dengan siklus menstruasi $(p$-value $=0,822)$. Namun, terdapat kecenderungan bahwa yang mengalami siklus menstruasi yang tidak teratur lebih banyak pada pada kelompok status gizi gemuk $(63,2 \%)$ dibandingkan dengan status gizi kurus (40,0\%). Penelitian ini sejalan dengan Prathita et al (2017) yang menunjukkan tidak ada hubungan antara status gizi dengan siklus menstruasi.

Siklus menstruasi tidak teratur lebih banyak pada kelompok stres ringan $(77,8 \%)$ dibandingkan dengan kelompok stres yang tidak mengalami stres $(33,3 \%)$. Analisis statistik menunjukkan ada hubungan antara tingkat stres dengan siklus menstruasi ( $p$-value $=0,037)$. Hasil ini sejalan dengan penelitian yang dilakukan oleh Tombokan et al (2017) yang juga menemukan ada hubungan antara stres dengan siklus menstruasi. korelasi antara stres dan siklus menstruasi dalam penelitian ini memiliki korelasi.

Tidak ada hubungan antara aktivitas fisik dengan siklus menstruasi ( $p$ $=0,246)$. Namun, terdapat kecenderungan bahwa kelompok yang mengalami siklus menstruasi tidak teratur memiliki aktivitas fisik sangat berat lebih banyak $(69,9 \%)$ dibandingkan dengan kelompok aktivitas fisik ringan (33,3\%). Hasil ini sejalan dengan penelitian yang dilakukan oleh Hikmah (2016), Suciati et al (2015). Yang juga menemukan tidak ada hubungan antara aktivitas fisik dengan keteraturan siklus menstruasi. Siklus menstruasi tidak teratur lebih banyak pada kelompok usia menarche cepat $(70,8 \%)$ dibandingkan dengan kelompok usia menarche normal $(35,0 \%)$.

Analisis statistik menunjukkan bahwa ada hubungan antara usia menarche dengan siklus menstruasi ( $p$ value $=0,028)$. Hasil penelitian ini sejalan dengan penelitian yang dilakukan oleh Hikmah (2016) yang juga menemukan adanya hubungan anatara usia menarche dengan siklus menstruasi.

\section{SIMPULAN}

Penelitian untuk mengetahui faktor-faktor yang berhubungan dengan 
siklus menstruasi pada siswi pada remaja putri kelas xi di SMA Negeri 6 Tangerang Selatan memperoleh beberapa kesimpulan. Sebagian besar remaja putri mengalami siklus menstruasi tidak teratur dibandingkan dengan responden yang memiliki siklus menstruasi yang teratur. Terdapat hubungan yang signifikan antara tingkat stres dan usia menarche dengan siklus menstruasi.

\section{DAFTAR PUSTAKA}

Hikmah, N. 2016. Stres Sebagai Faktor Dominan Terhadap Perbedaan Siklus Menstruasi Pada Siswi Kelas 10 Dan 11 Sma Negeri 44 Jakarta. Skripsi. Universitas Indonesia.

Kemenkes RI. 2010. RisetKesehatan

Dasar; Riskesdas. Jakarta: Balitbang Kemenkes RI.

Madaras, L. 2011. Ada Apa Dengan Tubuhku?. Jakarta : PT Indeks

Prathita, Yana Aurora. 2017. Hubungan

Status Gizi dengan Siklus

Menstruasi pada Mahasiswi Fakultas
Kedokteran Universitas Andalas. Jurnal.fk.unand.ac.id/index. php/jka/article/view/653. (Diakses tanggal 16 Mei 2019).

Pratiwi, A 2011. Hubungan Status Gizi Dengan Keteraturan Siklus Menstruasi Siswi SMA Negeri 1 Mojolaban. Skripsi, Universitas Sebelas Maret.

Pribakti B, 2010. Buku Panduan Praktis Kesehatan Reproduksi Wanita. Jakarta: Sagung Seto.

Suciati, Esti. 2015. Hubungan Antara Aktivitas Fisik Dengan Siklus Menstruasi Pada Siswi SMA Di KotaYogyakarta. Ilmu Keperawatan, UGM. Yogyakarta.

Tombokan, et al 2017. Hubungan antara stres dan pola siklus

menstruasi pada mahasiswa kepaniteraan klinik madya (coassistant) di RSUP Prof. Dr. R. D. Kandou Manado. Jurnal Bio-medik. Perhimpunanan Ahli Anatomi Indonesia. Manado. 